\title{
Potential of Lactic Acid Bacteria Isolated from Dangke and Indonesian Beef as Hypocholesterolaemic Agent
}

\author{
H. Burhan ${ }^{a}$, S. A. Priyambada ${ }^{\text {, }}$, E. Taufikc, \& I. I. Arief c,* $^{c}$ \\ aStudy Program of Animal Production and Technology, Faculty of Animal Science, Graduate School, \\ Bogor Agricultural University \\ 'Laboratory of Applied Microbiology, International Center for Biotechnology, Osaka University, \\ 2-1 Yamada-oka, Suita, Osaka, Japan \\ 'Department of Animal Production and Technology, Faculty of Animal Science, Bogor Agricultural University \\ Jalan Agatis, IPB Darmaga Campus, Bogor 16680 Indonesia \\ (Received 06-01-2017; Reviewed 17-02-2017; Accepted 18-07-2017)
}

\begin{abstract}
Lactobacillus fermentum strains were successfully isolated from dangke which was a fresh cheeselike product originating from Enrekang, South Sulawesi Province, Indonesia. In addition, Lactobacillus plantarum and Lactobacillus acidophillus were isolated from beef. This study aimed to investigate the ability of those $8 \mathrm{LAB}$ strains from dangke and beef in lowering cholesterol level by using in vitro study. Strain of Lactic acid bacteria used were L. fermentum strains (A323L, B111K, B323K, C113L, C212L), L. plantarum strains (IIA-1A5 and IIA-2C12), and L. acidophillus IIA-2B4. Variables observed were identification of Bile Salt Hydrolase (BSH) gene by Polymerase Chain Reaction (PCR), BSH activity and cholesterol assimilation. Phylogenetic tree indicated homology of L. plantarum IIA-IA5 was $98 \%$ to $\mathrm{BSH}$ gene of L. plantarum Lp529 with access code of FJ439771 and FJ439775 obtained from GenBank. The results demonstrated that eight strains of LAB isolated from dangke and beef that potentially showed cholesterol-lowering effects were L. fermentum B111K and L. plantarum IIA-1A5. L. fermentum B111K was able to assimilate cholesterol by $4.10 \%$ with assimilated cholesterol of $0.13 \mathrm{mg}$ in $10^{10}$ cells. In addition, L. plantarum IIA-1A5 had BSH gene and BSH activity, as well as the ability to assimilate cholesterol by $8.10 \%$ with assimilated cholesterol of $0.06 \mathrm{mg}$ in $10^{10}$ cells. It is concluded that L. fermentum B111K and L. plantarum IIA-1A5 were strains that showed cholesterol-lowering effects.
\end{abstract}

Keywords: lactic acid bacteria, bile salt hydrolase, assimilation, cholesterol, dangke

\section{ABSTRAK}

L. fermentum telah berhasil diisolasi dari dangke yang merupakan sejenis keju segar yang berasal dari Kabupaten Enrekang, Provinsi Sulawesi Selatan, Indonesia, dan L. plantarum dan L. acidophillus yang diisolasi dari daging sapi. Penelitian ini bertujuan untuk mengevaluasi kemampuan 8 strain BAL yang diisolasi dari dangke dan daging sapi dalam menurunkan kolesterol secara in vitro. Strain bakteri yang digunakan adalah L. fermentum (A323L, B111K, B323K, C113L, C212L), strain L. plantarum (IIA-1A5 dan IIA-2C12), dan L. acidophillus IIA-2B4. Peubah yang digunakan ialah uji keberadaan gen Bile Salt Hydrolase (BSH) yang diuji dengan Polymerase Chain Reaction (PCR), aktivitas BSH yang dianalisis secara deskriptif, dan asimilasi kolesterol yang dianalisis menggunakan ANOVA dengan 8 strain dan 3 ulangan. Hasil pohon filogenetik homologi gen BSH L. plantarum IIA-IA5 sebesar $\mathbf{9 8 \%}$ dengan L. plantarum Lp529 FJ439771 dan FJ439775 dari GenBank. Hasil penelitian menunjukkan bahwa dari 8 strain BAL isolat dangke dan daging sapi yang diuji, yang berpotensi menurunkan kolesterol adalah L. fermentum B111K dan L. plantarum IIA-1A5. L. fermentum B111K mempunyai kemampuan mengasimilasi kolesterol sebesar $4.10 \%$ dengan jumlah kolesterol terasimilasi dalam $10^{10}$ sel sebanyak 0.13 mg. L. plantarum IIA-1A5 terbukti memiliki gen BSH yang positif memiliki aktivitas BSH serta mampu mengasimilasi kolesterol sebesar $\mathbf{8 . 1 0} \%$ dengan jumlah kolesterol terasimilasi dalam $10^{10}$ sel sebanyak $0.06 \mathrm{mg}$. Dapat disimpulkan bahwa strain bakteri yang berpotensi menurunkan kolesterol adalah $L$. fermentum B111K dan L. plantarum IIA-1A5.

Kata kunci: bakteri asam laktat, bile salt hydrolase, asimilasi, kolesterol, dangke

${ }^{*}$ Corresponding author:

E-mail: irma isnafia@yahoo.com 


\section{INTRODUCTION}

World Health Organization (WHO) estimates that cardiovascular disease (CVD) will still be a main contributor of death in the world in 2030 (FAO/WHO, 2012). Elevated total cholesterol, specifically low density lipoprotein (LDL) cholesterol that exceeds normal limits may contribute to hypercholesterolemia. Consumption of diets containing high cholesterol is strongly associated with hypercholesterolemia. Consequently, LDL cholesterol level is excessive while good cholesterol HDL (High Density Lipoprotein) is insufficient to neutralize cholesterol.

To cope with hypercholesterolaemic condition, consumption of functional foods and anti-cholesterolaemic drugs has been considered. Unfortunately, these drugs were reported to have deleterious side effects on human health. In addition, the use of probiotic from specific strain has been currently developed to promote hypocholesterolaemic conditions. The cholesterol-lowering effect of lactobacilli is linked with the presence of bile salt hydrolase (BSH) that conjugates bile salts and assimilates cholesterol in the small intestine.

One of probiotic properties of Lactic Acid Bacteria (LAB) is its resistance to acid and bile salts (Liévin-Le Moal \& Servin, 2014; Arief et al., 2015; Syah et al., 2016). The ability of gut microbes to promote de-conjugation of bile acids was considered as a probiotic activity. Bile acids were synthesized in the liver from cholesterol, and secreted as conjugates of glycine and taurine into the duodenum, and would facilitate the absorption of fat and the enterohepatic circulation. During circulation in the gastrointestinal tract, bile salts could be modified by the intestinal microbiota through de-conjugation of bile salts by the activity of bile salts hydrolase (BSH) by removing the amino acid residues and form deconjugated bile acids (cholic acid) (Kumar et al., 2012).

Several studies have demonstrated that some LAB can reduce cholesterol in vitro and in vivo (Begley et al., 2006; Kimoto-Nira et al., 2007; Lye et al., 2010). In hyperlipidemic subjects, the consumption of probiotics could attenuate their cholesterol level, whereas decrease in triglyceride level was observed in normal subjects (Lye et al., 2010).

LAB is naturally found in food, and its use in the fermentation process is safe and beneficial to health, which in turn make it as GRAS (Generally Recognized as Safe) for human consumption (FAO/WHO, 2002). LAB strains isolated from dangke which was a fresh cheese-like product originating from Enrekang were L. fermentum A323L, L. fermentum B111K, L. fermentum B323K, L. fermentum C113L, and L. fermentum C212L (Syah et al., 2017). Meanwhile, Arief et al. (2015a) reported that LAB strains isolated from beef were L. plantarum IIA-2C12, L. plantarum IIA-1A5, and L. acidophillus IIA-2B4. Two LAB strains (L plantarum IIA- 2C12 and $L$ plantarum IIA-1A5) have been reported to produce plantaricin exhibiting inhibitory effects against pathogen bacteria (Ariel et al., 2012; Arief et al., 2013; Arief et al., 2015). LAB contained in food may show different effects on suppression of cholesterol level. Nuraida et al. (2011) reported that a total of $13 \mathrm{LAB}$ isolates from breast milk showed various abilities to assimilate cholesterol. Only Pediococcus pentosaceus I-A31, P. pentosaceus 2-B2, and $P$. pentosaceus 2-A16 that were able to exert the highest assimilation level. As previously mentioned, some LAB have the ability to decrease cholesterol levels. The capability and properties of each strain are various, thus selection of BSH presence in isolates from dangke (a fresh cheese like from the district of Enrekang, South Sulawesi) and beef is required. The cholesterol-lowering properties of lactic acid bacteria isolates from dangke and beef were evaluated according to their ability to assimilate cholesterol and the activity of enzymes. The study was aimed to select 8 strains of LAB from livestock products that have the potential to lower cholesterol. The specific objectives of this study were to analyze and identify the presence of $\mathrm{BSH}$ genes, $\mathrm{BSH}$ activity, and the ability of LAB isolates from dangke and beef to assimilate cholesterol.

\section{MATERIALS AND METHODS}

\section{Bacterial Strain and Culture Conditions}

LAB strains isolated from dangke were L. fermentum A323L, L. fermentum B111K, L. fermentum B323K, L. fermentum C113L, and L. fermentum C212L (Syah et al 2016). Dangke was taken from 3 different units of traditional dangke processing in South Sulawesi, produced from cow milk. LAB strains isolated from fresh beef were L. plantarum IIA-2C12, L. plantarum IIA-1A5, and L. acidophillus IIA-2B4 (Ariel et al, 2015a). LAB was maintained in MRS broth. Cultures were kept at $-20^{\circ} \mathrm{C}$, and incubated at $37^{\circ} \mathrm{C}$ before being used.

\section{Identification of BSH Gene using Polymerase Chain Reaction (PCR)}

DNA extraction was modified from the method prescribed by Arief et al. (2015a). LAB cultures incubated for $24 \mathrm{~h}$ at $37^{\circ} \mathrm{C}$ were centrifuged at $10000 \times \mathrm{g}$ (at $4^{\circ} \mathrm{C}$ ) for $1 \mathrm{~min}$, and the supernatant was discarded. The precipitate was added to $200 \mathrm{~mL}$ of solution I (25 $\mathrm{mM}$ Tris- $\mathrm{HCl}$ buffer $\mathrm{pH}$ 8.0, $10 \mathrm{mM}$ EDTA pH 8.0, 50 $\mathrm{mM}$ glucose), and then resuspended using pipette, and incubated for $5 \mathrm{~min}$ at room temperature. A total of 400 mL of solution II (1.2 N NaOH and 1\% SDS) were mixed gently and incubated with ice for $5 \mathrm{~min}$, and mixed with $300 \mathrm{~mL}$ of solution III $(60 \mathrm{~mL}$ of $5 \mathrm{M}$ potassium acetate,

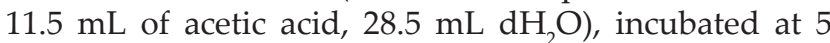
${ }^{\circ} \mathrm{C}$ and centrifuged at $10000 \times \mathrm{g}$ for $1 \mathrm{~min}$ at $4{ }^{\circ} \mathrm{C}$. The supernatant was transferred into a new tube, and added with $1 \mu \mathrm{L}$ of $1 \mathrm{mg} \mathrm{mL}^{-1} \mathrm{RNaseA}$, mixed gently and incubated at room temperature for $15 \mathrm{~min}$, then mixed with 2-propanol and centrifuged at $10000 \times \mathrm{g}$ for $10 \mathrm{~min}$ at 4 ${ }^{\circ} \mathrm{C}$. The supernatant was discarded. A total of $500 \mu \mathrm{L}$ of $70 \%$ ethanol were mixed gently and centrifuged for 1 min, and the supernatant was discarded and then dried. The solution was dissolved with Tris EDTA buffer (100 $\mu \mathrm{L})$ prior to PCR analysis.

Amplification of PCR BSH gene selection was performed by PCR with universal primers used by Kim et al. (2004), BSH F 1-24 (5'-AGTCCATATGT 
GCACTGGTGTCCGTTTCTCC-3'), $\quad$ BSH $\quad \mathrm{R}$ 951-931 (5'-AGTCAAGCTTCAAT CGGCGGTGATCAG CTCG$\left.3^{\prime}\right)$. The reaction mixture $(45 \mu \mathrm{L})$ which consisted of DNA templates $(3 \mu \mathrm{L})$, primer forward $(0.3 \mu \mathrm{L})$, primer reverse $(0.3 \mu \mathrm{L})$, deoxyribonucleic triphosphate (dNTPs) $(0.9 \mu \mathrm{L}), \mathrm{MgCl} 2(2.5 \mu \mathrm{L})$, Phire Hot Start II DNA Polymerase $(0.2 \mu \mathrm{L})$, Phire Buffer Reaction $5 X(9 \mu \mathrm{L})$, and double-distilled H2O $(28.8 \mu \mathrm{L})$. PCR amplification was performed at the initial temperature of $95^{\circ} \mathrm{C}$ for 15 min, followed by 35 cycles consisting of denaturation step at $94{ }^{\circ} \mathrm{C}$ for $1 \mathrm{~min}$, annealing at $55^{\circ} \mathrm{C}$ for $30 \mathrm{~s}$. Extension phase was performed at $72{ }^{\circ} \mathrm{C}$ for $1 \mathrm{~min}$. Post extension was applied for $10 \mathrm{~min}$ at $72{ }^{\circ} \mathrm{C}$. PCR products were taken and stored at $4{ }^{\circ} \mathrm{C}$ for next analysis using $1 \%$ agarose electrophoresis and for DNA sequencing.

A total of $1 \mu \mathrm{L}$ of loading dye were prepared in paraffin, then mixed with PCR product $(4 \mu \mathrm{L})$. The solution was then poured into the well using a micropipette, and added markers $(3 \mu \mathrm{L})$. Electrophoresis instrument was run at $100 \mathrm{~V}$ for $30 \mathrm{~min}$. The PCR product of observable DNA band was then sequenced to identify a gene. Sequencing of PCR products of BSH gene was conducted by using sequencer machine (ABI Prims 3100-Avant Genetic Analyzer) by First Base, Malaysia. Sequence identification is meaningful to determine gene identity by comparing international LAB isolate sequence data deposited in Genbank. The length of DNA product of L. plantarum IIA-1A5 BSH gene was 982 bp. Similarity test was carried out using online program BLAST NCBI (http://www.ncbi.nlm.nih.gov/). Electropherogram of DNA sequences were analyzed by MEGA 4 sofware to construct phylogenetic tree, by using neighbor joining method bootstrap 1000x.

\section{Activity of Bile Salt Hydrolase}

Enzymatic activity of BSH test was tested using procedures by Sedlackova et al. (2015) with some modifications. MRS agar at pH 5.6 (MRS broth, Bacteriology Agar, bile salt $0.3 \% \mathrm{w} / \mathrm{v})$ and $\mathrm{CaCl}_{2}(0.375 \mathrm{~g} / \mathrm{L})$. The petri dish was incubated anaerobically at $37^{\circ} \mathrm{C}$ for $48 \mathrm{~h}$. LAB was inoculated on MRSA by inoculating $80 \mu \mathrm{L}$ of culture in wells and test medium, and incubated for 72 $\mathrm{h}$ at $37^{\circ} \mathrm{C}$. BSH activity was characterized by the formation of bile salt precipitation zone (sediment) around colonies on agar medium containing $\mathrm{CaCl}_{2}$ and bile salt, because the cholic acid would react with $\mathrm{CaCl}_{2}$ to form precipitated salts (Sedlacova et al., 2015).

\section{Assimilation of Cholesterol by in vitro}

Cholesterol assimilation test was performed using produres by Tomaro-Duchesneau et al. (2014). Cholesterol PEG-600 (Sigma-Aldrich 250 mg) was incorporated into MRSB to reach final concentration of $100 \mu \mathrm{g} / \mathrm{mL}$. A total of $1 \%(\mathrm{v} / \mathrm{v})$ inoculum of LAB was refreshed for $24 \mathrm{~h}$ at $37{ }^{\circ} \mathrm{C}$. After $24 \mathrm{~h}$ of incubation, bacterial viability was measured by plate count method. For the analysis of cholesterol, LAB suspension was centrifuged at $4000 \mathrm{rpm}$ for $10 \mathrm{~min}$ at $4{ }^{\circ} \mathrm{C}$ to obtain the supernatant.
The obtained supernatant was transferred into a new tube of $500 \mu \mathrm{L}$, then added $500 \mu \mathrm{L}$ of $33 \% \mathrm{KOH}$ and $1 \mathrm{~mL}$ ethanol. The solution was stirred for $1 \mathrm{~min}$ and incubated at $37^{\circ} \mathrm{C}$ for $15 \mathrm{~min}$ at room temperature. For separation phase, the solution was added $1 \mathrm{~mL}$ $\mathrm{H}_{2} \mathrm{O}$ and $1.5 \mathrm{~mL}$ of hexane. The top layer of solution was transferred into $500 \mu \mathrm{L}$ tube for evaporation using nitrogen, and added with $1 \mathrm{~mL}$ of o-phthalaldehyde 50 $\mathrm{mg} / \mathrm{dL}$ dissolved with acetic acid, and then mixed with the sample. The mixture was then mixed with $250 \mu \mathrm{L}$ of $\mathrm{H}_{2} \mathrm{SO}_{4}$. The mixture was then incubated for $20 \mathrm{~min}$ at room temperature, and the absorbance was measured using spectrophotometer UV at wavelength of $570 \mathrm{~nm}$.

Standard curve of cholesterol concentrationabsorbance was made with cholesterol concentrations of $0 ; 3.91 ; 7.81 ; 15.6 ; 31.25 ; 62.5 ; 125$; and $250 \mathrm{ppm}$; and cholesterol in MRSB ( $22=0.9875)$. The assimilation of cholesterol by LAB probiotic strains were determined as follows:

1. Cholesterol assimilation $(\mu \mathrm{g} / \mathrm{mL})=$ $[\text { Cholesterol }(\mu \mathrm{g} / \mathrm{mL})]_{\text {ohour }}-[\text { Cholesterol }(\mu \mathrm{g} / \mathrm{mL})]_{24 \text { hour }}$

2. Percentage of assimilation $=$

[Cholesterol assimilation $(\mu \mathrm{g} / \mathrm{mL}) /$ Cholesterol $(\mu \mathrm{g} /$ $\left.\mathrm{mL})_{0 \text { hour }}\right] \times 100 \%$

3. Cholesterol assimilation in $10^{10}$ cell $=$

Cholesterol assimilation (mg/mL)/[Cell viability (cfu/ $\mathrm{mL}) \times 10^{10]}$

\section{Statistical Analysis}

Identification of Bile Salt Hydrolase (BSH) gene was conducted by Polymerase Chain Reaction (PCR) with 10 replications and $\mathrm{BSH}$ activity with three replications used descriptive analysis. Cholesterol assimilation data were statistically evaluated by analysis of variance (Anova) with three replications and if the differences were found among treatments, Duncan test will be used as post-hoc test (Mattjik \& Sumertajaya, 2013). Treatment was different strain of lactic acid bacteria (L. fermentum (A323L, B111K, B323K, C113L, C212L), L. plantarum (IIA-1A5 and IIA-2C12), and L. acidophillus IIA-2B4)

\section{RESULTS}

\section{Detection of BSH Genes}

Amplification of L. plantarum IIA-1A5 fragments was 900-1000 bp. Previous studies reported that $L$. plantarum had BSH gene, located in 800-1000 bp (Bin \& Jiang, 2011; Kim et al., 2004).

The result of PCR product and DNA sequences showed that BSH gene of L. plantarum IIA-1A5 demonstrated a similarity to L. plantarum Lp529 with access code of FJ439771 and FJ439775 (Figure 1). Furthermore, the alignment result indicated that base sequence of BSH gene of L. plantarum IIA-1A5 was well-aligned, and possessed fixed or similar base formation to the results of ClustalW analysis (Figure 1). 
BSH_LP. IIA FJ439771.1

clusta 7 co

BSH_LP.IIA

FJ439771.1

F]439775.1
Clusta 7 co

BSH_LP. IIA

FJ439775.1
Clusta 7 Co

BSH_Lp.IIA

FJ439775.1

clusta1 co

BSH_LP. IIA

FJ439771. 1

FJ439775.1
Clustal Co

BSH_LP. IIA

FJ439771. 1

FJ439775.1
Clusta1 Co

BSH_LP.IIA

FJ439771.1

FJ439775.1

BSH_LP.IIA

FJ439771.1

FJ439775.1
Clusta1 Co

BSH_Lp.IIA

FJ439775.1
clusta1 co

BSH_LP.IIA

FJ439771.1

FJ439775.1
Clusta 1 Co

BSH_LP. IIA

FJ439771.1

Fu439775.
Clusta $\mathrm{Co}$

BSH_LP. IIA

FJ439771.1

clustal co

BSH_LP.IIA

FJ439775.1

BSH_LP.IIA

FJ439775.1

BSH_LP.IIA FJ439771.1 FJ439775.1

BSH_LP.IIA FJ439771. 1

Clustal co

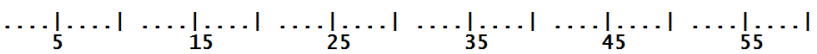
ATGTGTACTA GTITACGAT TCAAACCACG GCGGGTGATC AGTITTAAGC ACGCACCATG

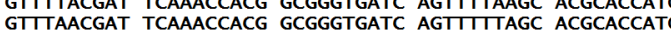
ATGTGTACTA GTITAACGAT TCAAACCACG GCGGGTGATC AGT11TAGC ACGCACCATG

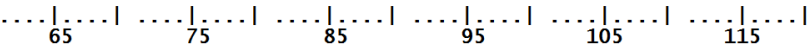
GACTTTGCTT TTGAACTTGG TGGTCGACCA GTGGCAATCC CACGGAATCA ACATTTTGAC GACTTTGCTT TTGAACTTGG TGGTCGACCA GTGGCAATCC CACGGAATCA CCATITTGAC

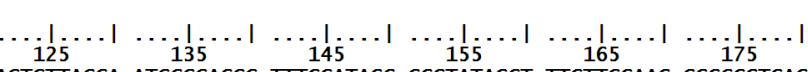
AGTGTTACCA ATGCGGACGG TITGGATAGC CCGTATAGCT TTGTTGGAAC GGGCCGTGAC AGTGTTACCA ATGCGGACGG TIITGATAGC CCGTATAGCT TTGTTGGAAC GGGCCGTGAC

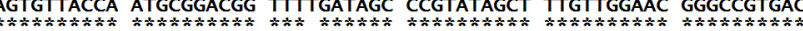

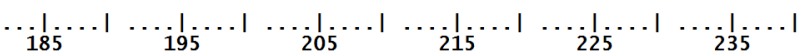
TTAAATGGCT ATATCTITGT CGATGGTGTC AAGGAGCACG GGGTCAGTGC TGCTGCACTC TTAAATGGCT ATATCTITGT CGATGGTGTC AATGAGCACG GGGTCAGTGC TGCTGCACTC

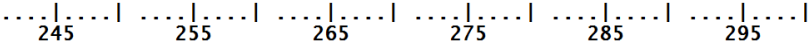
TATITCTCGG GACAAGCTCA CTITACTCAG CAAACTAAGG CTGGCAAGGT TAACTTCGCA TATTCTCGG GACAAGCTCA CTITACTCAG CAGACTAAGG CTGGCAAGGT TAACTTGGCA

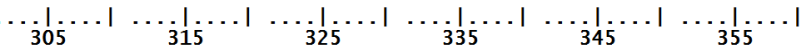
CCCACGAAG TITAATGTG GATITAGGA ACCGTGAAGA GCACCGCTGA ATTASGCGAA CCCCACGAAG TIITAATGTG GATITIAGGA AACGTGAAGA GCACCGCTGA ATTAGGCGAA CCCCACGAAG TITAATGTG GATITAGGA AACGTGAAGA GCACCGCTGA ATTAGGCGAA

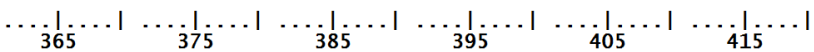
CGGATTGCTG ACTTGAACGT GATGTAAGCC GCCGCGCCAC TATTGAATAT TGTGGTACCA CGGATTCCTG ACITGAACGT GATGGAAGCC GCCGCGCCAC TATTGAATAT TGTGGTACCA CGGATTGCTG ACTTGAACGT GATGGAAGCC GCCGCGCCAC TATTGAATAT TGTGGTACCA

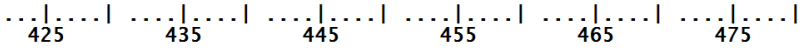
CTAAACTGGA TCATTAGTGA CAAGAGTGGT TCTACTTACG TCTTAGAATT GGAAATGAC CTACACTGGA TCATTAGTGA CAAGAGTGGT TCTACTTACG TCTTAGAATT GGAAAATGAC CTACACTGGA TCATTAGTGA CAAGAGTGGT TCTACTTACG TCTTAGAATT GGAAAATGAC

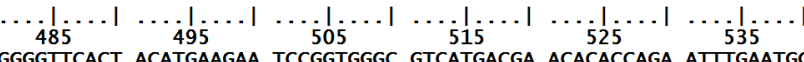
GGTGTTCACT ACATGAAGAA TCCGGTGGGC GTCATGACGA ACACACCAGA ATTIGAATGG GGTGTTCACT ACATGAAGAA TCCGGTGGGC GTCATGACGA ACACACCAGA TाTGAATGG

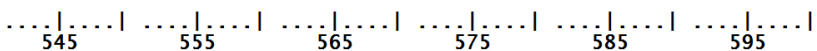
CATCTCAAGA ATTTGAGTAA TTACGTCAAC TTACAACCCG GCCCTCATCC TAGTCGTCAA CATCTCAAGA ATTTGAGTAA TTACGTCAAC TTACAACCCG GCCCTCATCC TAGTCGTCAA CATCTCAAGA ATTIGAGTAA TTACGTCAAC TTACAACCCG GCCCTCATCC TAGTCGTCAA

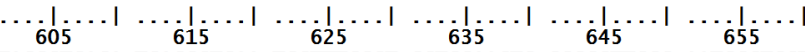
TACGGTGACA TGACGGTGAA TCCTITCGGT CCTGGAACTG GGGCGTTGGG AATGCCTGG TACGGTGACA TGACGGTGAA TCCTTTCGGT CCTGGAACTG GGGCGTTGGG AATGCCTGGT TACGGTGACA TGACGGTGAA TCCTITCGGT CCTGGAACTG GGGCGTTGGG AATGCCTGGT

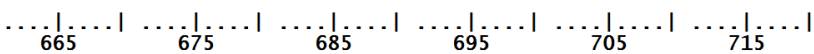
GGCTATACGT CAGTTGCACG CTTCGTTCG ACGGTCTTCA TGCGTGAACA TACGGATGCA CAGTTCACG CTTCGTCGG ACGGTCTTCA TGCGTGAACA GACTATACGT CAGTTGCACG CTTCGTTCGG ACGGTCTTCA TGCGTGAACA TACGGATGCA

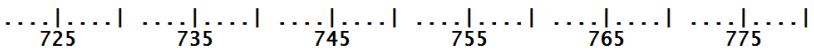

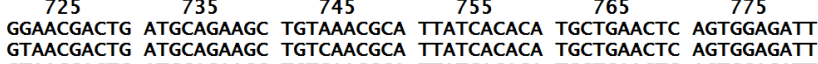
GTAACGACTG ATGCAGAAGC TGTCAACGCA TIATCACACA TGCTCACTC AGTGGAGATT

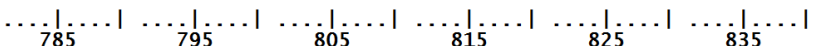
CCTAAGGGCG TTAAGATGCA AGATAACGGG ACGCCAGATT ATACCCAGTA CCGCGCCTAT CCTAAGGGCG TTAAGATGCA AGATAACGGG ACGCCAGATT ATACCCAGTA CCGCGCCTAT CCTAAGGGCG TTAAGATGCA AGATAACGGG ACGCCAGATT ATACCCAGTA CCGCGCCTAT

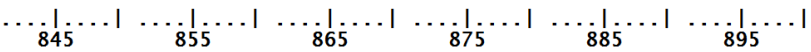
ATGAGCATGA ATGAACCAGC ATITTACATG CAACCATACG GGGATCAGAC GATTACGCGG ATGAGCATGA ATGAACCAGC ATITACATG CAACCATACG GGGATCAGAC GATTACGCGG

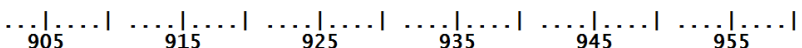
GTCGAATTGA CACCAGCTTT AATGACGGCC GCGCAACCGA CTGAATTTGA ATTAAAGACA GTCGAATTGA CACCAGCTTT AATGACGGCC GCGCAACCGA CTGAATTTGA ATTAAAGACA GTCGAATTGA CACCAGCTIT AATGACGGCC GCGCAACCGA CTGAATTTGA ATTAAAGACA

Figure 2. Aligment of BSH L. plantarum IIA-1A5 with BSH L. plantarum Lp529 bsh FJ439771 and BSH FJ439775 from GenBank (Continued on the next page). 


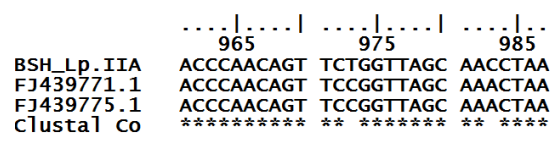

Figure 1. Aligment of BSH gene L. plantarum IIA-1A5 with BSH L. plantarum Lp529 bsh FJ439771 and bsh FJ439775 from GenBank

Phylogenetic tree was constructed using MEGA6 software, neighbor joining method with boothstrap 1000x, and presented in Figure 2. The dendogram indicated that the homology of L. plantarum IIA-IA5 was $98 \%$ to $\mathrm{BSH}$ gene of L. plantarum Lp529 with access code of FJ439771 and FJ439775 obtained from GenBank. The similarity of L. plantarum IIA-IA5 and L. plantarum Lp529 BSH FJ439771 and FJ439775 had bootstrap value of $95 \%$. This value denotes that topology at that branch is considered to be very accurate or consistent, even though it was tested by other methods of construction of phylogenetic tree (Horiike et al., 2009).

\section{Activity of BSH (Bile Salt Hydrolase)}

BSH activity by in vitro on 8 strains of LAB is presented in Table 1. L. plantarum IIA-1A5 was confirmed to have $\mathrm{BSH}$ activity indicated by the white precipitate formed, and the white precipitate was salt. The condition indicated deconjugation activity against bile salts (Sedlackova et al., 2015). Detection of BSH activity is due to the production of BSH by L. plantarum IIA-1A5. The result was augmented by the presence of the BSH gene in L. plantarum IIA-1A5. This finding was in accordance with the report of Sedlackova et al. (2015), that Lactobacillus have BSH activity except Lactobacillus

BSH FJ439771 BSH FJ439775 BSH_Lp.IIA-1A5

\subsection{2}

Figure 2. Phylogenetic tree of BSH L. plantarum IIA-1A5 with gen BSH L. plantarum Lp529 bsh FJ439771 and bsh FJ439775 from GenBank.

Table 1 . The result of bile salt hydrolase activity

\begin{tabular}{clc}
\hline No. & \multicolumn{1}{c}{ Strain } & BSH activity \\
\hline 1 & L. fermentum A323L & $\mathrm{N}$ \\
2 & L. fermentum B111K & $\mathrm{N}$ \\
3 & L. fermentum B323K & $\mathrm{N}$ \\
4 & L. fermentum C113L & $\mathrm{N}$ \\
5 & L. fermentum C222L & $\mathrm{N}$ \\
6 & L. plantarum IIA-1A5 & $\mathrm{P}$ \\
7 & L. acidophillus IIA-2B4 & $\mathrm{N}$ \\
8 & L. plantarum IIA-2C12 & $\mathrm{N}$ \\
\hline
\end{tabular}

Note: N: Negative; P: Positive. strains isolated from raw cow's milk, cheese and the colostrum.

\section{Cholesterol Assimilation}

Assimilation of cholesterol on 8 strains isolated from dangke and beef is presented in Table 2 . Differences in the assimilation ability were confirmed by previous study of Tomaro-Duchesneau et al. (2014) each strains was $L$. reuteri NCIMB 11951, L. reuteri NCIMB 701359, L. reuteri NCIMB 702655, L. reuteri NCIMB 701089, L. reuteri NCIMB 705626, L. fermentum NCIMB 5221, L. fermentum NCIMB 8829, L. fermentum NCIMB 2797, L. rhamnosus ATCC 53103 GG, L. acidophillus ATCC 314, and L. plantarum ATCC 14917. L. fermentum B111K and L. plantarum IIA-1A5 showed assimilation level of $4.10 \%$ and $8.10 \%$, respectively. Table 2 shows that both strains indicate significant difference in the percentage of the assimilated cholesterol $(\mathrm{P}<0.05)$. L. plantarum IIA-1A5 exhibited a significantly higher percentage of cholesterol assimilation. Assimilated cholesterol, in terms of $\mathrm{mg}$ cholesterol assimilated per $10^{10}$ cell in MRS is presented in Table 2. When bacterial cell counts were taken into account, the results obtained were different from those previously described. Cholesterol assimilation of L. fermentum B111K and L. plantarum IIA-1A5 was significantly different, $0.13 \mathrm{mg}$ of cholesterol assimilated per $10^{10} \mathrm{cfu}$ and $0.06 \mathrm{mg} / 10^{10} \mathrm{cfu}$, respectively.

\section{DISCUSSION}

$\mathrm{BSH}$ in bacteria provides a special advantage for probiotic bacteria which grow in a highly competi-

Table 2. Percent of cholesterol assimilation containing $100 \mu \mathrm{g} /$ $\mathrm{mL}$ of cholesterol PEG-600 for 24 hours and the amount of cholesterol assimilation expected in a probiotic dose containing $10^{10}$ cell

\begin{tabular}{cccc}
\hline No. & Strain & $\begin{array}{c}\text { Cholesterol } \\
\text { assimilated } \\
(\%)\end{array}$ & $\begin{array}{c}\text { Cholesterol } \\
\text { assimilated } \\
\left(\mathrm{mg} / 10^{10} \mathrm{cfu}\right)\end{array}$ \\
\hline 1 & L. fermentum A323L & - & - \\
2 & L. fermentum B111K & $4.10 \pm 0.36^{\mathrm{a}}$ & $0.13 \pm 0.03^{\mathrm{a}}$ \\
3 & L. fermentum B323K & - & - \\
4 & L. fermentum C113L & - & - \\
5 & L. fermentum C222L & - & - \\
6 & L. plantarum IIA-1A5 & $8.10 \pm 0.65^{\mathrm{b}}$ & $0.06^{+} 0.01^{\mathrm{b}}$ \\
7 & L. acidophillus IIA-2B4 & - & - \\
8 & L. plantarum IIA-2C12 & - & - \\
\hline
\end{tabular}

Note: Means in the same column with different superscripts differ significantly $(\mathrm{P}<0.05)$. 
tive environment such as the gastrointestinal tract by providing a better resistance to bile salts. The presence of this enzyme was useful for reduction of cholesterol (Begley et al., 2006). Cholesterol-lowering effect by BSH in vitro was revealed by $\mathrm{BSH}$ activity of $\mathrm{LAB}$.

In this experiment, L. plantarum IIA-1A5 was confirmed to show BSH activity in 8 isolates tested. Several studies showed that Lactobacillus strains had different BSH activities (Hae-Keun et al., 2008; Mahrous, 2011). Liong \& Shah (2005) and Lye et al. (2010) observed the quantitative activity of BSH by measuring the levels of amino acids (glycine/taurine) produced from conjugated bile salts. $\mathrm{BSH}$ activity $(\mathrm{U} / \mathrm{mL})$ was defined as the amount of enzyme to form $1 \mu \mathrm{mol}$ of free amino acids per minute from the substrate. Their experiment indicated that the activity of BSH in L. acidophilus, Lactobacillus casei, Lactobacillus bulgaricus ranged from 0.25-1.81 U/ $\mathrm{mL}$.

The plausible mechanism of cholesterol reduction by $\mathrm{BSH}$ activity was attributed to the increase in the secretion of bile salt hydrolase, resulting in de-conjugated bile acids in the form of free cholic acid. The substance was difficult to be reabsorbed through the enterohepatic circulation and, therefore, it was secreted through the feces. This condition led to the increase in cholesterol demand in the body, and consequently blood cholesterol level was reduced (Surono, 2004).

The level of cholesterol assimilation was affected by the number of bacteria cultured for $24 \mathrm{~h}$ in MRS media. The presence of the bacteria was positively correlated with the degree of assimilation. Percentage of cholesterol assimilation by L. plantarum IIA-1A5 was higher than that of L. fermentum B111K, while in assimilated cholesterol of $10^{10}$ cells, the value of L. fermentum B111K was higher than L. plantarum IIA-1A5. The similar result was reported by Tomaro-Duchesneau et al. (2014) that percentage of cholesterol assimilation of Lactobacillus reuteri NCIMB 702656 was higher compared to L. plantarum ATCC 14917, while in assimilated cholesterol of 1010 cells, L. plantarum ATCC 14917 showed the higher value than $L$. reuteri NCIMB 702656.

Cholesterol assimilation was also influenced by the ability of LAB to bind cholesterol. The cholesterol binding by $\mathrm{LAB}$ was due to the peptidogly can abundance in the cell wall. The cell walls were able to bind or absorb cholesterol into the cell and used for the formation of cell membranes (Kumar et al., 2012).

In addition, cholesterol absorption by LAB activity in the gastrointestinal tract provides desirable effects. This absorption promotes the reduction of cholesterol availability, leading to a lower concentration of cholesterol in blood vessels. Ultimately, this action is useful to reduce the risk of hypercholesterolemia (Liong \& Shah, 2005; Lye et al., 2010).

\section{CONCLUSION}

The strains of lactic acid bacteria that exhibited cholesterol-lowering effect were L. fermentum B111K and L. plantarum IIA-1A5. L. fermentum B111K was able to assimilate cholesterol, while L. plantarum IIA-1A5 had BSH gene, BSH activity, and showed cholesterol assimi- lation. The homology of L. plantarum IIA-IA5 was $98 \%$ to BSH gene of L. plantarum Lp529 FJ439771 and FJ439775 obtained from GenBank.

\section{ACKNOWLEDGMENT}

Authors thank Prof. Dr. Kazuhito Fujiyama, International Center for Biotechnology, Osaka University Japan for supporting primers.

\section{REFERENCES}

Arief, I.I., B. S. L. Jenie, T. Suryati, G. Ayuningtyas, \& A. Fujiawan. 2012. Antimicrobial activity of bacteriocin from indigenous Lactobacillus platarum 2C12 and its application on beef meatball as biopreservative. J. Indonesian Trop. Anim. Agric. 37: 90-96. https://doi.org/10.14710/ jitaa.37.2.90-96

Arief, I. I., Jakaria, T. Suryati, Z. Wulandari, \& E. Andreas. 2013. Isolation and characterization of plantaricin produced by Lactobacillus plantarum Strains (IIA-1A5, IIA-1B1, IIA-2B2). Med. Pet. 36: 91-100. http://dx.doi.org/10.5398/ medpet.2013.36.2.91.

Arief, I. I., B. S. L. Jenie, M. Astawan, K. Fujiyama, \& A. B. Witarto. 2015a. Identification and probiotic characteristics of lactic acid bacteria isolated from Indonesian local beef. Asian J. Anim. Sci. 9: 25-36. https://doi.org/10.3923/ ajas.2015.25.36

Arief, I. I., B. S. L. Jenie, E. Andreas, \& A. Yuneni. 2015b. Plantaricin IIA-1A5 from Lactobacillus plantarum IIA-1A5 displays bactericidal activity against Staphilucoccus aureus. Benef. microbes. 6: 603-613. https://doi.org/10.3920/ BM2014.0064

Begley, M., C. Hill, \& C. G. M. Gahan. 2006. Bile salt hydrolase activity in probiotics. Appl. Environ. Microbiol. 72: 17291738. https://doi.org/10.1128/AEM.72.3.1729-1738.2006

Bin, L. \& J. Yujun. 2011. Cloning of Bile salt hydrolase gene and its expression in lactic acid bacteria. J. Northeast Agric. Univ. (English edition) 18: 48-53. https://doi.org/10.1016/ S1006-8104(12)60009-9

Chang-qing, Y., \& L. Rong. 2015. Cloning and Expression of Bile Salt Hydrolase Gene from Lactobacillus plantarum M1UVS29. J. Northeast Agric. Univ. (English Edition) 22: 6066. https://doi.org/10.1016/S1006-8104(15)30033-7

FAO/WHO. 2012. WHO working group report on drafting guidelines for the evaluation of probiotics in food. London Ontario, Canada 30.

Hae-Keun, O., J. Y. Lee, S. J. Lim, M. J. Kim, G.-B. Kim, J. H. Kim, et al., 2008. Molecular cloning and characterization of a bile salt hydrolase from Lactobacillus acidophilus PF01. J. Microbiol. Biotechnol. 18: 449-456.

Horiike, T., D. Miyata, K. Hamada, S. Saruhashi, T. Shinozawa, S. Kumar, et al., 2009. Phylogenetic construction of 17 bacterial phyla by new method and carefully selected orthologs. Gene 429: 59-64. https://doi.org/10.1016/j. gene.2008.10.006

Kim, G.-B., C. M. Miyamoto, E. A. Meighen, \& B. H. Lee. 2004. Cloning and characterization of the bile salt hydrolase genes (bsh) from Bifidobacterium bifidum strains. Appl Environ. Microbiol. 70: 5603-5612. https://doi.org/10.1128/ AEM.70.9.5603-5612.2004

Kimoto-Nira, H., K. Mizumachi, M. Nomura, M. Kobayashi, t. 1. Y. Fujita, T. Okamoto, et al., 2007. Lactococcus sp. as potential probiotic lactic acid bacteria. Jpn. Agric. Res. Q. 41: 181-189. https://doi.org/10.6090/jarq.41.181

Kumar, M., R. Nagpal, R. Kumar, R.Hemalatha, V. Verma, A. Kumar, et al., 2012. Cholesterol-lowering probiotics as potential biotherapeutics for metabolic diseases. Exp. Diabetes 
Res. 2012: 902917. https://doi.org/10.1155/2012/902917

Liévin-Le Moal, V., \& A. L. Servin. 2014. Anti-infective activities of lactobacillus strains in the human intestinal microbiota: from probiotics to gastrointestinal anti-infectious biotherapeutic agents. Clin. Microbiol. Rev. 27: 167-199. https://doi.org/10.1128/CMR.00080-13

Liong, M. \& N. Shah. 2005. Acid and bile tolerance and cholesterol removal ability of Lactobacilli strains. J. Dairy Sci. 88: 55-66.

Lye, Huey-Shi, Rahmat-Ali, G. Rusul, Liong, \& Min-Tze. 2010. Mechanisms of cholesterol removal by lactobacilli under conditions that mimic the human gastrointestinal tract. Int. Dairy J. 20: 169-175. https://doi.org/10.1016/j. idairyj.2009.10.003

Mahrous, H. 2011. Probiotics bacteria from Egyptian infants cause cholesterol removal in media and survive in yoghurt. Food Nutr. Sci. 02: 150-155. https://doi.org/10.4236/ fns.2011.22021

Mattjik, A. A. \& Sumertajaya, M. 2013. Perancangan Percobaan dengan Aplikasi SAS dan Minitab Jilid 1. Bogor (ID): IPB Pr.
Nuraida, L., S. Winarti, Hana, \& E. Prangdimurti. 2011. Evaluasi in vitro terhadap kemampuan isolat bakteri asam laktat asal air susu ibu untuk mengasimilasi kolesterol dan mendekonjugasi. J. Teknologi dan Industri Pangan. 22:46-46

Sedlackova, P., S. Horackova, T. Shi, M. Kosova, \& M. Plockova. 2015. Two Different Methods for Screening of Bile Salt Hydrolase Activity in Lactobacillus Strains. Czech J. Food Sci. 33: 13-18. https://doi.org/10.17221/299/2014-CJFS

Surono, I. S. 2004. Probiotik Susu Fermentasi dan Kesehatan. YAPMMI, Jakarta.

Syah, S. P., C. Sumantri, I. I. Arief, \& E. Taufik. 2017. Isolation and identification of indigenious lactic acid bacteria by squencing the 16SrRNA from dangke, a traditional cheese from Enrekang, South Sulawesi. Pakistan Journal of Nutrition: 16: 384-392. https://doi.org/10.3923/ pjn.2017.384.392

Tomaro-Duchesneau, C., M. L. Jones, D. Shah, P. Jain, S. Saha, \& S. Prakash. 2014. Cholesterol assimilation by Lactobacillus probiotic bacteria: an in vitro investigation. Biomed. Res. Int. 2014: 380316. https://doi.org/10.1155/2014/380316 